\title{
Exploring the Importance of Employing Bio and Nano- Materials for Energy Efficient Buildings Construction
}

\author{
Mona Naguib1, and Mohamed El Fakharany ${ }^{2}$ \\ ${ }^{1}$ BSC, PHD., Teacher of Architecture, Pharos University in Alexandria, Alexandria, Egypt \\ ${ }^{2}$ BSC, M.SC., Teacher assistant of Architecture, Pharos University in Alexandria, Alexandria, Egypt \\ 1 mona.naguib@pua.edu.eg,] \\ 2 m.fakharany@pua.edu.eg
}

\begin{abstract}
The continued and increasing use of ordinary building materials to house the ever-growing world population ensures growing contributions of carbon (C) to the active carbon cycle through carbon dioxide (C02) emissions from combustion and chemical reactions in the raw material to the atmosphere. To minimize this, materials should be conserved, reduce their unnecessary use, produce them more benignly and make them last longer, recycle and reuse materials. Thus, paper will focus on exploring alternative building materials and systems that can be developed in order to balance atmospheric carbon dioxide. It also presents the Bioinspired architecture approach that embraces the eco-friendly practices of using Biomaterials and Nano-materials for sustainable dwelling construction through a number of examples that shows how a building can be strongly related to its site.
\end{abstract}

Keywords - Bio-Nano Material, Sustainable Dwelling Construction, Cradle To Cradle Materials, Energy Efficient Building Materilas.

\section{INTRODUCTION}

Building materials are literally part of the air human breath. Compared to most other materials in the living world, they are also much longer-lived, with a much longer use phase. Unfortunately, Current use of materials for building construction especially for the housing sector is running down natural systems, destroying community and biodiversity, debasing work, and suppressing all kinds of possibilities for real development. With the exception of wood, sand, gravel, and natural stone, the manufacture of the greater part of most conventional building materials used today is based on the use of hydraulic cement, lime, fired brick, steel, aluminum, and plastic which are fossil-fuel intensive in their manufacture.
Following the philosophical principles of Cradle to Cradle "waste equals food" will also help in creating a healthy regenerative built environment which will benefit people and other living creatures as well as safeguarding the biodiversity.

\section{SUSTAINABLE MATERIALS FOR BUILDING SKINS:}

An essential dimension of detoxifying production and achieving regenerative sustainable design is increasing the use of renewable and bio-based materials that can be more safely reabsorbed by natural systems. As well as using materials that help preserve the biodiversity of the place. [2] To connect buildings to place; architects should start by making the interface of buildings better suited to its environment. This interface occurs in a building's first line of defense to the environment, the building Skin, which includes the exterior walls, roof, and exterior openings. However, current envelopes are seen as barriers from the outside world, instead of filters like a natural skin. Thus, to make improvements in the building skin's efficiency and construction it is necessary to look on how a sustainable regenerative building skin should function.

These are as follows: [1]

1. Protection from the natural elements.

2. Environmentally-friendly manufacturing as well as adding positive contribution.

3. Not be harmful to the natural environment at the end of its life

4. Integrate multiple systems within thin membrane.

5. Regulate transfer of heat, air, water and energy efficiently. 
6. Be adaptable to its local environment and respond accordingly.

7. Be beautiful.

\section{EXAMPLES OF NATURAL AND BIOMATERIALS}

\section{A. Hempcrete}

Two materials are produced from the hemp plant stem, fiber from the outer bark and wood chips from the core. Every part of the hemp plant can be used for applications like building materials (Hempcrete , fibreboard and insulation). Hemp wood chips or hurds are mixed with lime-based binders and water to create a bio-composite breathable masonry material termed hempcrete. The lime is typically combined with a small amount of cement to reduce the curing time.

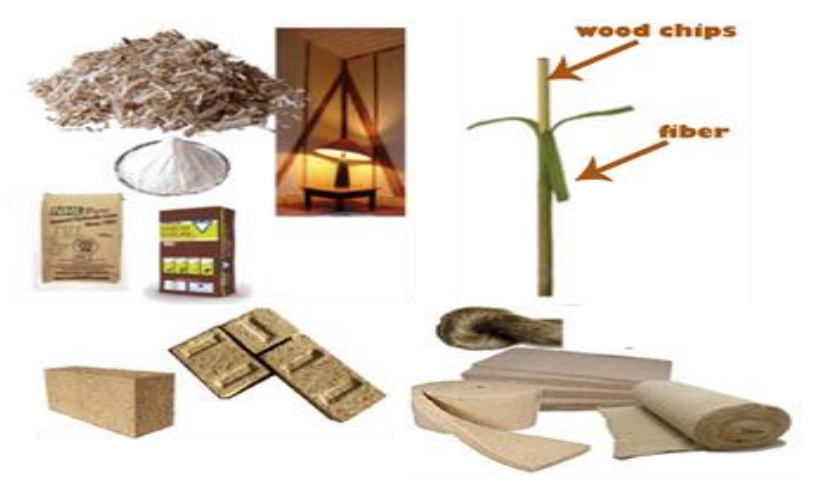

Fig.1. Shows Hemp wood chips are mixed with lime to create hempcrete Bricks and insulation sheets

Source:http://internationalhempbuilding.org, retrieved 1-5-2013

The common application of hempcrete in buildings is to be used as infill in timber frame walls. It is also used to build monolithic walls and floors and to fill roof cavities. This method has been used in France since the early 1990's to construct non-weight bearing insulating infill walls supported by a timber frame.

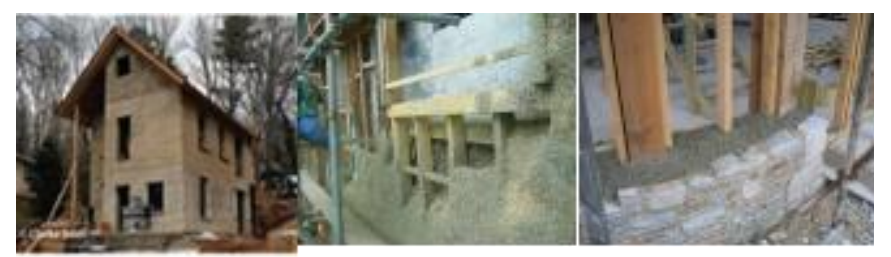

Fig.2. Shows that hempcrete can be cast manually around a timber frame using a shuttering system,

Source: http://internationalhempbuilding.org, retrieved 1-5-2013
Hempcrete bricks have the capability of being selfsupporting removing the need for a timber frame. Local style of vernacular buildings can be easily built with hempcrete bricks.

Hempecrete has many sustainable advantages such as: [3]

1. Hemp is a rapidly growing, annually renewable plant.

It takes one hectare of land to grow, in approximately four months, sufficient hemp to build a three-

bedroom house. This estimated production amounts to four tones of material per acre per year.

\section{Hempcrete is carbon negative.}

Buildings built with hempcrete achieve a low carbon footprint as hemp absorbs nearly twice its dry weight in $\mathrm{CO} 2$ during growth, providing a lower carbon footprint to all materials it is used to create. The carbon trapped in the hemp offsets the carbon not only of the hemp production but also the residual carbon from the lime binder production after reabsorption of carbon as the lime cures. A $300 \mathrm{~mm}$ hemcrete wall absorbs in its construction $40 \mathrm{~kg}$ per $\mathrm{m} 2 \mathrm{CO} 2$. A typical brick and block wall emits $100 \mathrm{~kg}$ giving a net benefit of $140 \mathrm{~kg}$. [2]

3. Hemp does not require agrochemicals in its cultivation.

Providing a clean air and clean soil as well as clean water

4. Hempcrete is also recyclable at the eventual end of the life of the building.

5. The walls are breathable

This controls moisture and condensation and improves internal air quality. Hempcrete regulates the temperature and humidity of a building; in some cases completely eliminating the need for heating and cooling systems, resulting in huge energy savings.

\section{Hempcrete does not rot}

[when used above ground due to presence of lime] and is mostly biodegradable. [3] 


\section{B. Rammed Earth Construction and compressed Earth blocks}

Unfired clay bricks and rammed earth are two more ancient technologies that are finding increasing use in modern sustainable buildings. Clay and sand are mixed with water and then placed in formwork to form bricks, walls or columns. Often soil from the building site is used, resulting in an extremely low embodied energy structural element with high thermal mass. Conventional fired clay bricks require large amounts of energy for their production and result in the release of large amounts of carbon dioxide (MacDougall 2007). Compressed Earth Blocks (CEB's) are energy-efficient, comfortable, durable and cost-effective. In addition, they are insect-proof, bullet-proof, earthquake-resistant and fire-proof. The thermal insulation capacity of CEB buildings are up to 10 times more efficient than concrete block building, meaning cool housing in summer and less heating required in winter. Unlike modern adobe blocks, the CEB's are entirely natural and they don't use asphalt or other potentially toxic additives. Workers employing hand presses can make up to 500 blocks a day, and all the bricks necessary for a modest house in a week. Hydraulic machines can make all the blocks for a large house in a day. CEB construction has been employed around the world, from Latin America to Africa to India and the Middle East. CEBs are stronger in compression than regular adobe blocks. [4] Unfired clay and rammed earth must be protected from exposure to the elements. To completely waterproof the unit with the more expensive option is to wrap the walls in chicken wire and plaster the whole unit, or else special sealant coats are available such as Earth Cote elastomeric polymer coating developed in South Africa which can be painted on in two coats - primer and finishing coat. [3]

- Soil Selection and quality control:

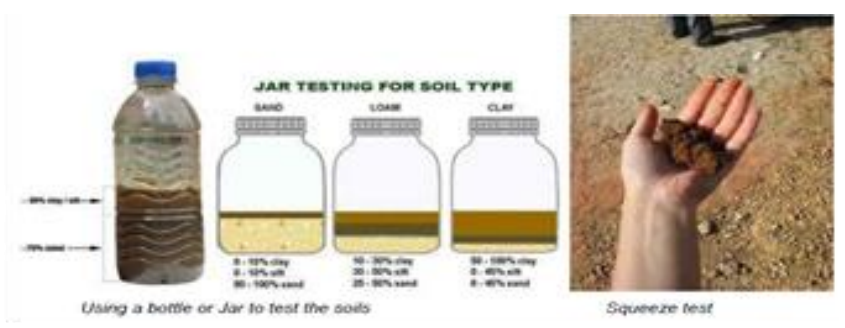

Fig.3. Shows the two types of soil selection tests to form compressed earth block

Source: http://use-it.co.za/, Retrieved 4-5-2013
There are a number of tests used to select the right soils and ensure that the blocks produced will make strong blocks. One of them is the squeeze test and the other one is the jar or bottle test. Soil with a clay content of between 10 and $50 \%$ is the better selection. The strength of the blocks will vary depending on the clay content and type. Once the right soils have been tested and sourced - transport these to the production site (keep it close to the source) and prepare soils for production. They should be dried to ambient moisture conditions $(<12 \%)$ in the sun and then blended through the soils blender (adding stabilizer of lime or cement at $5 \%$ to ensure greater stability and to waterproof the blocks) and then fed through to the block production system. Although clay is essential in earth block construction, blocks that contain too much clay may crack. In some parts of the world builders use Portland cement to stabilize the clay - stabilisation is only required for the lower course of blocks for waterproofing. Lime is a good stabilizing ingredient for the CEB blocks if it can be sourced locally as it is cheaper than cement and also a more natural ingredient. The exact recipe used to manufacture CEBs will depend on the soil composition of the region. [8]

\section{- Block production:}

Blended and sifted soils are loaded into the block press machine. Several adjustments are required to set the thickness of the blocks to the desired size, and then the sensor system takes over for mass production. Fuel is saved because each hydraulic ram machine consumes only about 10 gallons or 38 litres of diesel a day. A "set" of CEB equipment, when fully functioning, will employ in excess of 50 employees. This will include soil selection, soil preparation, equipment operators, block handlers, house builders, roofers, electricians, plumbers, glazers, finishers, security individuals, managers, truck drivers and inspectors. . [8]
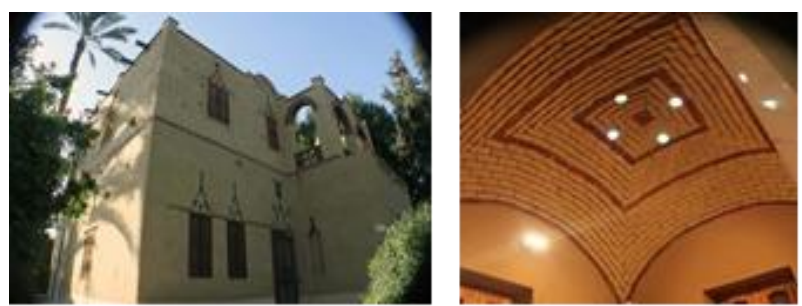

Fig.4. Shows using of earth construction in the three systems Villa, by Adel Fahmy, Giza, Egypt. Source: Photo taken by Architect Ahmed abd el Gawad 


\section{Solar-generated Building Material from Seawater (SBM):}

Solar-generated Building Material from Seawater (SBM) is an alternative building material and system that has been developed in order to balance atmospheric carbon dioxide. Using electricity from renewable sources, limestone-storing carbon can be precipitated from seawater with simultaneous production of hydrogen, oxygen, and chlorine gas. These installations could also produce SBM for use elsewhere, replacing building materials made with hydraulic cement like concrete blocks, walls, and slabs, even foundations. SBM can substitute for bricks made of fossil-fuel fired lime and clay, not only reducing $\mathrm{CO} 2$ emissions, but subtracting carbon from the carbon cycle. [11]

Wolf Hilbertz, German architect and inventor is the father of sea-creation, had mimicked the electrolytic deposition of sea-shell-like minerals from seawater and had found a way to use sunlight to turn the minerals in seawater into limestone for underwater and dry land constructions. The limestone structures in the sea will facilitate the growth of corals and provide habitat for fish and other coral reef species; Coral reefs are one of the most complex marine ecosystems, important to sea life and protective of shorelines from erosion. The method is sustainable, environmentally safe, and economically and biologically feasible. [11]

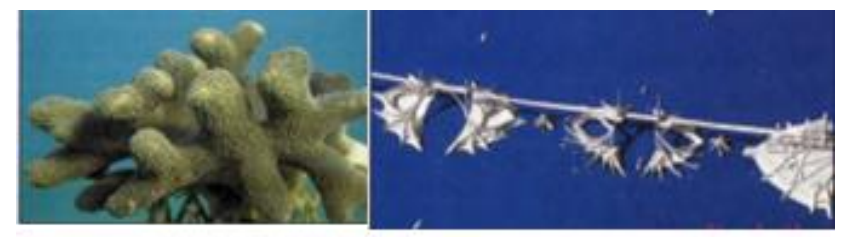

Fig.5. Autopia, ocean settlement with membrance construction. Photo: W.H. Hilbertz. Source: www.globalcoral.org Retrieved 9$5-2013$

This idea is derived from Coral blocks, which have been utilized for centuries as a dependable and lasting building material for structures and roads.

- Calcium Carbonate as a Building Material:

Nature uses controlled and uncontrolled biomineralization processes to build a variety of structures. They produce about 60 different minerals [9]. $\mathrm{CaCO} 3$ is one of the more abundant minerals involved in the processes which are often on such a scale that they affect ocean/atmosphere chemistry and form major parts of sedimentary rocks. When one molecule $\mathrm{CaCO} 2$ is precipitated from seawater, charge balance requires the formation of one molecule of carbonic acid and super saturation of carbonic dioxide. If this escapes to the atmosphere, carbon is removed from the hydrosphere, but $\mathrm{CO} 2$ added to the atmosphere. Therefore, deposition of $\mathrm{CaCO} 3$ is often seen as a source of atmospheric $\mathrm{CO} 2, \mathrm{SBM}$ is a sink for carbon although its direct effect on the atmosphere has to be treated as controversial. To fully assess the role of SBM in the global atmospheric balance the net effect of all electrolytic and biogenic reactions needs to be measured experimentally. At the same time, as a result, global warming would be mitigated. A note of caution needs to be taken in equating carbon removal from the ocean with carbon removal from the atmosphere. [11]

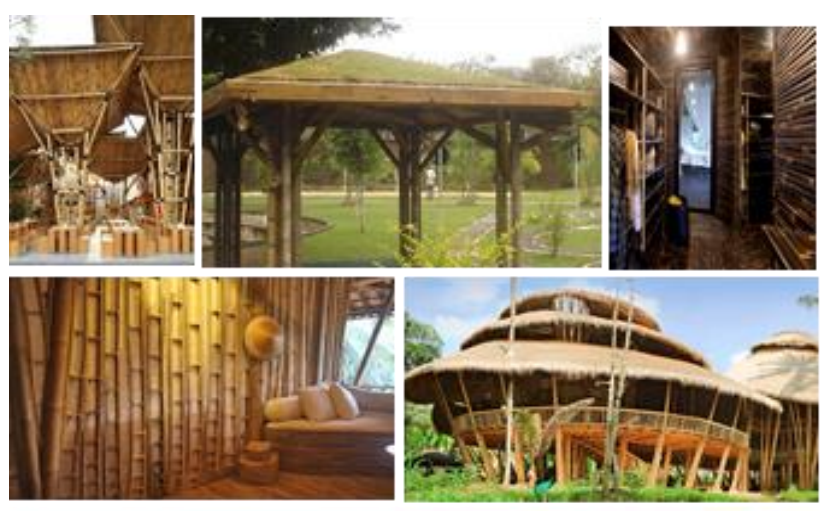

Fig 6. Examples of the application of bamboo structural material in the building industry

Source: http://www.inspirationgreen.com/bamboobuildings.html, Retrieved 4-6-2013

\section{Bambo:}

Bamboo is a grass native which has been used as a building material dating back to $3500 \mathrm{BC}$ (Kennedy, J.F., 2002:125-131).It is the fastest growing woody plant on the planet. Most species produce mature fiber in about three years, much more rapidly than any tree species. Some species grow by up to one meter a day, and the majority reaches a height of 30 meters or more. It is adaptable to most climatic conditions and soil types, acts as an effective carbon sink and helps counter the greenhouse effect. According to the Zero Emissions Research Institute (ZERI), a bamboo forest can sequester 17 times as much carbon as a typical tree forest. Some species grow as much as 39 inches in a day. Also, due to bamboo's high nitrogen consumption, bamboo helps 
mitigate water pollution, as it takes in and transforms nutrient wastes when planted alongside manufacturing zones, intensive livestock farming, and sewage treatment facilities. It can also desalinate seawater. It is being used increasingly in land stabilization to check erosion and conserve soil. It can be grown quickly and easily, even on degraded land, and harvested sustainably on three- to five-year rotation. Bamboo is a truly renewable, environmentally friendly material. [8]

In building construction, Bambo is used as framing, roofing, flooring, wall matting, ceilings, scaffolding, boards and panels, plywood, concrete reinforcement, connecting stakes, and more. Bamboo in buildings can help reduce the amount of wood, steel and concrete needed. As a substitute for wood, it can take great pressure off forests, and contribute to local self-reliance, since great quantities can be produced in small areas. It has great compressive and tensile strength, and has shown great resistance to earthquakes. [2]

Possibly the major factor contributing to the view of bamboo as a temporary material is its lack of natural durability. It is susceptible to attack by insects and fungi. It deteriorates rapidly in contact with moisture. Its service life may be as low as one year when in ground contact. However, the durability of bamboo can be greatly enhanced by appropriate specification and design and by careful use of safe and environmentally friendly preservatives such as boron. [8]

\section{E. Timber from sustainably managed forests:}

Cutting down trees to make buildings does not immediately sound eco-friendly either, but if sourced from sustainably managed forests (like those in Europe and North America), it can be more environmentally sensitive.

A sustainable forest is a forest that is carefully managed so that when mature trees are felled they are replaced with seedlings that eventually grow into mature trees. In this way the forest is constantly renewed and will continue to exist providing natural materials for all generation. The forest is a working environment, producing wood products such as wood pulp for the paper / card industry and wood based materials for furniture manufacture and the construction industry.

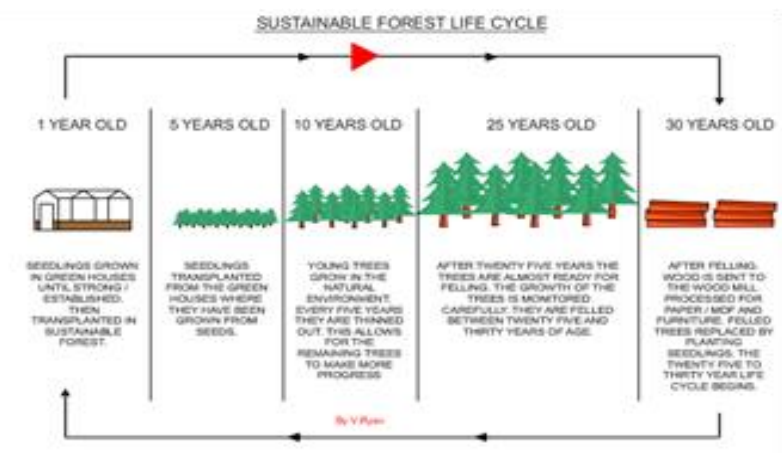

Fig.7. Shows the life cycle of trees in a sustainable forest, Source:

http://www.technologystudent.com/prddes1/susenv1.html, Retrieved 12-5-2013

Green says that the modern wood materials have been used for around 20 years, but until recently they have been quite niche or used only in low-rise buildings. What has changed is the way in which architects and builders are thinking about using wood. Swapping cement and steel for timber is the vision of a number of environmentally minded architects who are planning high-rise buildings across the world. Wood buildings lock in carbon dioxide for the life cycle of a structure, while the manufacture of steel and concrete produces large amounts of $\mathrm{CO} 2$-- the International Energy Agency (IEA) estimated that for every 10 kilos of cement created; six to nine kilos of CO2 are produced. [17]

\section{- Example Of High Rise Wooden Building:}

The Stadthaus, Murray Grove is one of the highest modern wooden buildings in London, Completed in 2009. It's a nine-story residential building with height of 30 meters. It is the tallest building in Europe structured entirely of wood. Even the lift shafts and stairwells are made from wood. It illustrates a groundbreaking approach of building material selection that can help achieve carbon-neutral (or even carbon-negative) buildings with current technology. It is built of solid slabs of timber, used for floors and walls, with no other structural framework. Much like plywood, but on a larger scale, the slabs are made of layers of solid 1" thick boards, crosslaminated into large slabs up to $30 \mathrm{ft}$. long. 


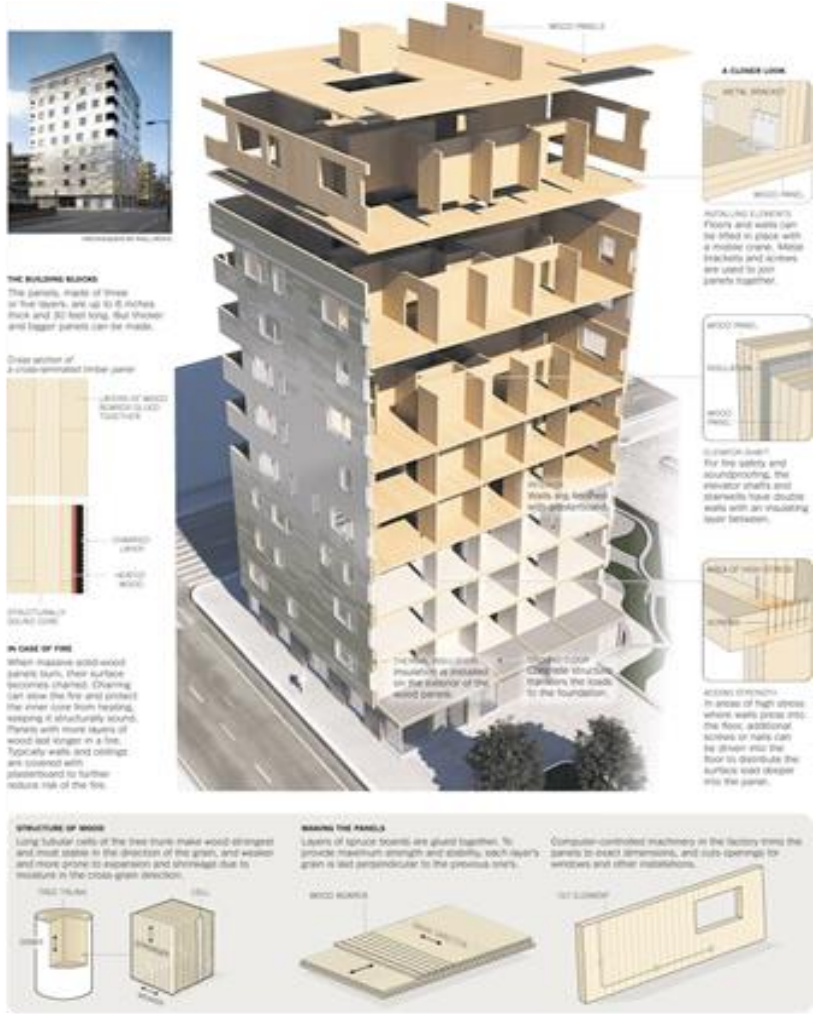

Fig.8. Shows the wood structure of the 9 stores Stadthaus, Murray Grove residential building.

Source

http://www.nytimes.com/interactive/2012/06/05/science/0605timber.html? r=0, retrieved 13-7-2016

cross-laminated timber used on the Stadthaus is classified as air-tight, making it one of London's most energy efficient buildings. These are quite strong, resilient, and the solid construction offers excellent fire-resistance and acoustic separation properties, compared to more typical hollow "stud" walls. [12]

Wood is a renewable resource and all of the adhesives and chemicals used in the manufacture of this system are non-toxic. Compared to conventional steel and concrete construction, embodied energy was reduced an equivalent of 340 tons of carbon emissions. This calculation allows for the fact that the panels were manufactured in Austria and transported to the project site in England. Unfortunately, there is not yet any manufacturing source in the United Kingdom. Ideally, the building would be made of lumber from Scotland, reducing transportation and further reducing the embodied energy. In addition, approximately 200 tons of carbon are "locked in" the wood material, which alone is equivalent to the energy that will be used to heat, cool and operate the building for twenty years.
Thus, the building will have a negative carbon footprint until almost 2030. Wood is biodegradable, the wood slabs will easily disassembled for some reuse when the day comes for its demolition, following the concept of "cradle-to-cradle". The exterior cladding of the building consists of fiber-cement panels, made from $70 \%$ wood-waste products. [12]

\section{EXAMPLES OF NANO-MATERIALS FOR GLASS WINDOW AND CURTAIN WALLS}

Glass is a sustainable, fully recyclable material and a resource efficient material which is made of abundant natural raw material such as sand and glass waste which provides great environmental benefits such as contributing to mitigating climate change and saving precious natural resources. It is also used to generate renewable energy through solar-thermal and photovoltaic applications as well as contributing in safeguarding people's health and well-being. Window glass is completely different than traditional glass bottles, which are the most recyclable items. By contrast, it is nearly impossible to recycle window glass. Though the two products may seem virtually the same, there are actually some notable differences. Bottle glass has a different chemical composition and melting temperature than window glass, meaning the two products can't be recycled together. Window glass is a trickier proposition. Most windows come attached to metal or wooden frames and have to be disassembled, which is labor intensive and expensive. Picking out the different types of window glass poses a bit more of a challenge. Is the glass tinted or not? Is it safety glass or tempered glass? Different glass products have a different melting point from container glass. All these different subsets of window glass also cannot be combined to create a new product. However, there are still nontraditional ways to properly recycle it. Creative industry professionals are finding other uses for old windows. The glass can be melted and remanufactured into Fiberglas. Ground glass can be incorporated into glassphalt, a glass and asphalt blend. Broken glass is combined with concrete to create terrazzo flooring and countertops. Old windows can also be reused as is or use them to construct greenhouses or cold frames for the garden. However, there are great efforts to create more innovative bio-regenerative glass materials by following the Biomimetics approach 


\section{A. Sunclean, Self Cleaning Glass}

The advanced architectural glasses, such as Sunclean, Self cleaning glass, Solarban solar control, low-e glasses and Oceans of Color spectrally selective tinted glasses can contribute to green building projects through their ability to transmit light and block solar heat, which can minimize reliance on artificial lighting and air conditioning.[13]

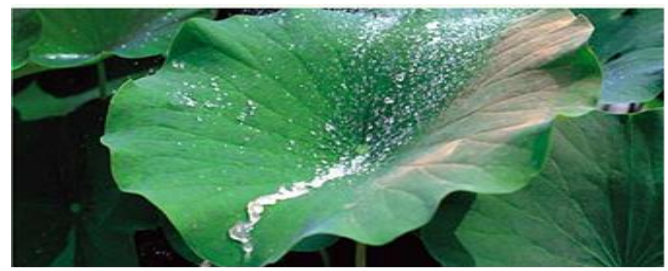

Fig.9.Hydrophobic surface allows self-cleaning: sacred lotus

Source:

http://www.asknature.org/strategy/714e970954253ace485abf1c ee376ad8, Retrieved 4-5-2013

SunClean glass is inspired by self-cleaning mechanism of lotus plants, the glass self-cleaning is formulated with a proprietary coating that becomes "photocatalytic" and "hydrophilic" after prolonged exposure to sunlight as it reacts with UV rays to disintegrate organic deposits and repel dust during rain.

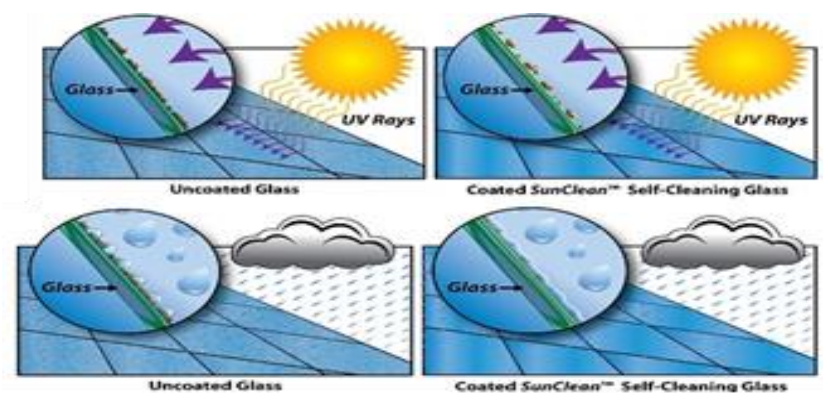

Fig.10. Diagram shows the difference between conventional uncoated glass \& innovative coated sun-clean, self-cleaning glass,

\section{Source:}

http://www.ppg.com/corporate/ideascapes/glass/products/suncl ean/Pages/suncleanglass.aspx, Retrieved 18-5-2013

Photocatalysis enables the coating to gradually break down organic materials that land on its surface when exposed to UV light.

Hydrophilicity causes water to sheet when it strikes the coating so that decomposed materials are naturally rinsed away when it rains. Some types of the self cleaning glass are also Cradle-to-Cradle Certified which make them more sustainable and environmental stewardship. [14]

\section{B. Dye Solar Cell Technology:}

Dye solar cell is described as "artificial Photosynthesis" using an electrolyte, a layer of titania and ruthenium dye sandwiched between glass. [16]

The main difference from a traditional solar cell is that Dye solar cell does not require high-energy consuming silicon, but is instead made of titanium dioxide, used in white paint and toothpaste.
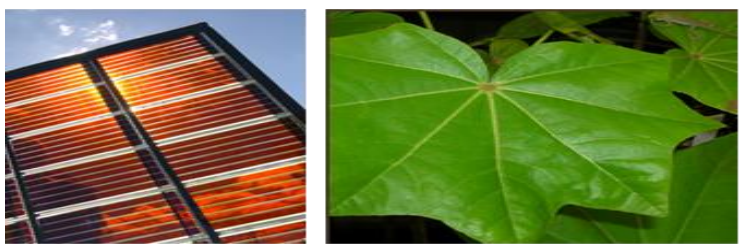

Fig.11. Dye solar cell inspired from the Photosynthesis of tree leaves,

Source:

http://www.asknature.org/product/b57e64dd3a2a1a9d36a92a5 a51ef7293, retrieved 4-5-2013

The dye in cells absorbs light just like chlorophyll in photosynthesis, releasing an electron that is conducted by the chemical electrolyte in the cell. Light striking the dye excites electrons which are absorbed by the titania to become an electric current many times stronger than found in natural photosynthesis in plants. [16]

It also can be directly incorporated into buildings by replacing conventional glass panels rather than taking up roof or extra land area.

Compared to conventional silicon based photovoltaic technology, Dye solar cell technology has lower cost and embodied energy in manufacture, and it produces electricity more efficiently even in low light conditions and regardless of the panel's orientation. [16]

\section{CRADLE TO CRADLE CONCEPT}

Cradle-to cradle design raises an entirely different agenda. Rather than seeing materials as a waste management problem as in the cradle-to grave system, cradle-to-cradle design is based on the closed-loop nutrient cycles of nature, in which there is no waste. By modeling human designs on these 
regenerative cycles, cradle-to-cradle design seeks, from the start, to create buildings, communities and systems that generate wholly positive effects on human and environmental health. Not less waste and fewer negative effects, but more positive effects, buildings that make oxygen, sequester carbon, fix nitrogen, distill water, provide habitat for thousands of species, accrue solar energy as fuel, build soil, create microclimate, change with the seasons, belong to the place and are beautiful.

The milestone of the cradle to cradle certification is based on the principle that WASTE=FOOD; that everything should be designed so that its components are either biological nutrients, food for natural systems capable of being composted and returned to the earth as food for more plants and animals, or technical nutrients, food for industry capable of being easily separated and properly recycled. In the natural world, everything is conceived of and designed to be food. When everything (every material, manufacturing process and emission) is food for one system or the other, then humanity will be indeed benefitting the environment. So that building should act like a tree and cites like a forest. A tree, for example, is not "zero-emitting." It emits oxygen and nutrients for soil, while purifying water and providing habitat for multiple species. This total quality framework has been designed to support companies in creating products that are "good" rather than simply "Less bad." [6]

\section{A. The C2C philosophical principles:}

McDonough and Braungart had investigated three key concepts for any environmental design for new products as well as for buildings design, which are: All Materials in Continues cycle, Use Renewable energy only and respect diversity. Despite the publication of the manifesto "c2c in Architecture" in 2009 as well as the "cradle to cradle criteria for the built environment" by Douglas Mulhall and Michael Braungrat in 2010, in which issues such as the C2C design principles were clarified in building sector, there is still an insufficiently detailed handbook for the realization and evaluation of the $\mathrm{C} 2 \mathrm{C}$ building project. The $\mathrm{C} 2 \mathrm{C}$ building projects provide their own interpretation by combining elements from C2C philosophy with elements from "sustainable building", "energy-efficient building", "Bio-eco logical building" and others. [7]

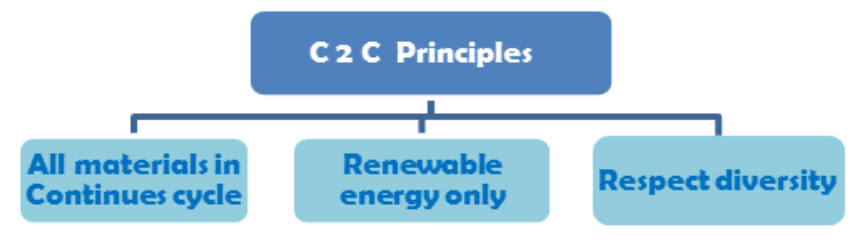

Fig.12. Diagram shows the Cradle to Cradle Principles

\section{A. All Materials in Continues Cycle:}

"Waste Equal Food" it is the conceptual basis for the C2C philosophy. All products should be made using materials that can be recycled with minimal environmental impact to be reused as biological or technological nutrients.

\section{B. Use Renewable Energy only:}

"Current Solar Income" McDonough and Braungart use this phrase to argue that manufacturing processes should use energy from the sun or other renewable sources instead of fossil fuels which are earth's stored solar energy reserve.

\section{Respecting Diversity:}

It is about evaluating the impact of industrial processes on all plant and animal life or as McDonough and Braungart say: "All the children of all species for all time". [5]

\section{CONCLUSION}

Looking back to learn from nature as well as using natural materials in building structure will help in creating more energy efficient buildings. It is highly recommended to create a community that appreciate this concept and to be aware about the benefit that will touch their quality of life by creating an energy efficient environment.

\section{REFERENCES}

[1] Yowell J., Biomimetic Building Skin: A Phenomenological Approach Using Tree Bark As Model, 2011, A Thesis Submitted To The Graduate Faculty In Partial Fulfillment Of The Requirements For The Degree Of Master Of Architecture, Norman,University Of Oklahoma

[2] Milani B., Building Materials in a Green Economy: Community-based Strategies for Dematerialization. A thesis submitted to the Department of Adult Education and 
Counsel,2005, ling Psychology and the Institute for Environmental Studies For The Degree Of Doctor of Philosophy

[3] Mukherjee A, Structural Benefits Of Hempcrete Infill In Timber Stud Walls, ., 2012,A thesis submitted to the Department of Civil Engineering In conformity with the requirements for the degree of Master of Applied Science, Queen's University Kingston, Ontario, Canada January,

[4] Kennedy, J.F., M.G. Smith And C. Wanek, The Art of Natural Building. 2002, Published by New Society Publishers, Gabriola Island, BC

[5] Mcdonough W., Buildings like trees, cities like forests, The Catalogue of the Future, 2002., Published by Pearson Press.

[6] Braungart M., Mcdonough W. And Bollinger A., Cradle to Cradle Design: Creating healthy emissions- a strategy for eco-effective product \& system Design, in the international Journal of Cleaner production, 2007, published by Elsevier, 15, 2007, 1337-348

[7] Debacker W., Greerken T., Stouthuyen P., Vann Holim M., Vrancken K. And Willems S., "Sustainable building, materials and Cradle to Cradle. A survey of current project practices", Published by Danny Wile, OVAM, Mechelen, June 2011,

[8] Jayanett L. \& Follett P., April- september 2003, bamboo in construction: status and potential, sustainable building and construction published by the unep industry and environment, volume 26 no.2-3, page 64-65

[9] Lowenstam, H.A. And Weiner, S., 1989, on biomineralization, published by oxford university press

[10] "building an earth block home: the magic building material" [web page] available at : http://use-it.co.za/wpcontent/uploads/2011/09/use-it-building-anearth-block-home.pdf (accessed (may 4th 2013)

[11] "ocean-grown homes: wolf hilbertz wants to build low-cost housing from the sea". turnbul a., september 1997, [web page] available at: http://www.globalcoral.org/ocean-

grown\%20homes.htm(accessed (august 24th 2012))

[12] "murray grove apartment building, london, england" 2013, by the green education foundation (gef), [web page] available at: http://www.greeneducationfoundation.org/greenbuilding-program-sub/case-studies/896-murraygrove-apartment-building.html((accessed (may 16th 2013))

[13] "product scorecard, architectural glass (uncoated and coated, ppg industries, inc", 2011, by cradle to cradle products innovation institute, [web page] available at: http://c2ccertified.org/products/scorecard/archite ctural_glass_uncoated_and_coated, ((accessed (may 18th 2013))

[14] virginia apartment complex first to showcase solarban 70xl/sunclean glass" 2009-2012, by the american ceramic society, [web page] available at: http://ceramics.org/ceramictechtoday/tag/suncle an-glass/, ((accessed (may 18th 2013))

[15] "product scorecard, architectural glass (uncoated and coated, ppg industries, inc", 2011, by cradle to cradle products innovation institute, [web page] available at: http://c2ccertified.org/products/scorecard/archite ctural_glass_uncoated_and_coated, ((accessed (may 18th 2013))

[16] "smit solar ivy" 13 december 2012, by the biomimicry 3.8 institude, [web page] available at:

http://www.asknature.org/product/256b9f497821 497773d9f0c442ab367a((accessed (may 19th 2013))

[17] "can wooden skyscrapers transform concrete jungles?" march 15,2012, by michael green architect, [web page] available at : http://edition.cnn.com/2012/03/15/tech/ecowood-skyscrapers/index.html?iphoneemail (accessed (May 15th 2013)). 